\title{
Alkenes from $\beta$-lithiooxyphosphonium ylides generated by trapping $\alpha$-lithiated terminal epoxides with triphenylphosphine
}

\author{
David. M. Hodgson* and Rosanne S. D. Persaud
}

\author{
Full Research Paper \\ Address: \\ Department of Chemistry, Chemistry Research Laboratory, University \\ of Oxford, Mansfield Road, Oxford, OX1 3TA, UK \\ Email: \\ David. M. Hodgson* - david.hodgson@chem.ox.ac.uk \\ * Corresponding author \\ Keywords: \\ alkenes; epoxides; lithiation; synthetic methods; ylide
}

\author{
Beilstein J. Org. Chem. 2012, 8, 1896-1900. \\ doi:10.3762/bjoc.8.219 \\ Received: 06 September 2012 \\ Accepted: 15 October 2012 \\ Published: 07 November 2012 \\ Associate Editor: I. Marek \\ (C) 2012 Hodgson and Persaud; licensee Beilstein-Institut. \\ License and terms: see end of document.
}

\begin{abstract}
Terminal epoxides undergo lithium 2,2,6,6-tetramethylpiperidide-induced $\alpha$-lithiation and subsequent interception with $\mathrm{Ph}_{3} \mathrm{P}$ to provide a new and direct entry to $\beta$-lithiooxyphosphonium ylides. The intermediacy of such an ylide is demonstrated by representative alkene-forming reactions with chloromethyl pivalate, benzaldehyde and $\mathrm{CD}_{3} \mathrm{OD}$, giving a $Z$-allylic pivalate, a conjugated $E$-allylic alcohol and a partially deuterated terminal alkene, respectively, in modest yields.
\end{abstract}

\section{Introduction}

$\beta$-Lithiooxyphosphonium ylides $\mathbf{4}$ are useful intermediates in synthesis as they react with a variety of electrophiles to provide a convergent entry to alkenes, often with high regio- and stereocontrol (Scheme 1) [1-9]. These ylide intermediates can be generated by initiating a Wittig reaction between an aldehyde $\mathbf{1}$ and a phosphorane $\mathbf{2}$ at low temperature in the presence of lithium salts, which promote ring opening of the initially formed oxaphosphetane $\mathbf{3}$, followed by deprotonation typically using PhLi [5].

We recently reported the use of methylenetriphenylphosphorane (2) $\left(\mathrm{R}^{2}=\mathrm{H}\right)$ in this chemistry for the synthesis of $Z$-allylic esters such as 6 [8] and conjugated $E$-allylic alcohols such as 7 [9]. $\beta$-Lithiooxyphosphonium ylides $4\left(\mathrm{R}^{2}=\mathrm{H}\right)$ can also be generated by double deprotonation of $\beta$-hydroxy prima- ry phosphonium salts [10-19], where the latter are obtained from $\mathrm{Ph}_{3} \mathrm{P}$ and 1,2-halohydrins [10-16,19] or (in the presence of acid) from terminal epoxides $[17,18]$. In seeking a more concise way than the above approaches to $\beta$-lithiooxyphosphonium ylides $4\left(\mathrm{R}^{2}=\mathrm{H}\right)$, we were attracted to the possibility of phosphines intercepting $\alpha$-lithiated terminal epoxides 10 (Scheme 2) and report here the results of that study. Such carbenoids $\mathbf{1 0}$ are unstable, but they can be easily formed from terminal epoxides 8 by using hindered lithium amides, such as lithium tetramethylpiperidide (9, LTMP) [20], and have shown synthetically useful carbene reactivity (e.g., cyclopropanation [21,22], dimerization [23-25]). The reaction of carbenes and carbenoids with heteroatom lone pairs is a popular strategy to access ylides [26], although phosphonium ylides for carbonyl-olefination chemistry are usually prepared by deprotonation of phos- 


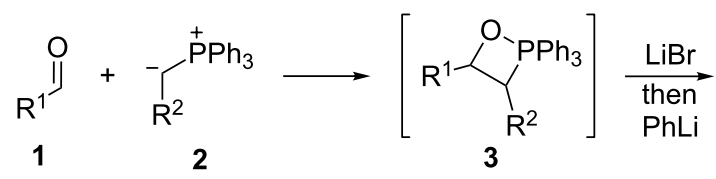

$$
\left[{\underset{\mathrm{R}^{2}}{\mathrm{O}}}_{\mathrm{P}^{1}}^{\mathrm{OLi}} \stackrel{+}{\mathrm{PPh}}_{3}\right]
$$

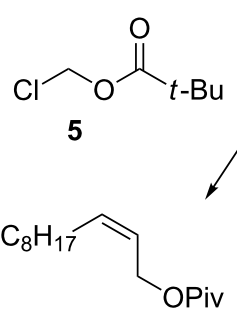

$666 \%, Z>99 \%$

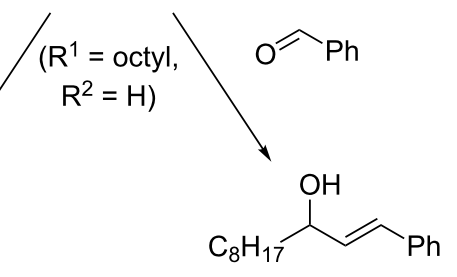

$746 \%, E>99 \%$
Scheme 1: Typical generation of ylide 4 and reaction examples.

phonium salts [1-4]. In fact, phosphine trapping of lithium carbenoids followed by carbonyl olefination has been little studied since Seyferth and Wittig independently reported the synthesis of chloro alkenes in modest yields (20-30\%) by this route (using $\mathrm{CH}_{2} \mathrm{Cl}_{2}$ and $\mathrm{BuLi}$ in the presence of $\mathrm{Ph}_{3} \mathrm{P}$ ) over half a century ago [27-31].

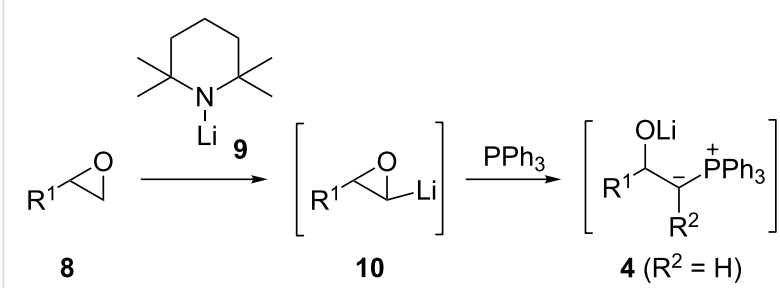

Scheme 2: Proposed ylide 4 formation from a-lithiated epoxide 10.

\section{Results and Discussion}

The feasibility of generating and reacting $\beta$-lithiooxyphosphonium ylides $4\left(\mathrm{R}^{2}=\mathrm{H}\right)$ derived directly from epoxides began with studies to produce allylic ester 6 under LTMP-based conditions for $\alpha$-lithiation of terminal epoxides [20-22] but with $\mathrm{Ph}_{3} \mathrm{P}$ also present (Scheme 3). Encouragingly, a red-orange colour, which is characteristic of a $\beta$-lithiooxyphosphonium ylide $[8,9]$, gradually developed (mixing only LTMP and $\mathrm{PPh}_{3}$ in $\mathrm{THF}$ at $0{ }^{\circ} \mathrm{C}$ for $24 \mathrm{~h}$, gave no colour change from an initial yellow solution), becoming very intense after $3 \mathrm{~h}$, although some epoxide 11 was still present after $24 \mathrm{~h}$ (TLC monitoring); the reduced activity of LTMP may be due to phosphine coordination [32]. At this point, following cooling to $-78{ }^{\circ} \mathrm{C}[8]$, chloromethyl pivalate (5) was added, resulting in the isolation of allylic ester $\mathbf{6}(23 \%)$. Only the $Z$-isomer of 6 was observed, indicating that stereoselectivity is not altered by this method of $\beta$-lithiooxyphosphonium ylide formation. The presence of $\mathrm{LiBr}$ (1 equiv) from the start of an otherwise identical reaction made no significant difference to the yield of $Z$-allylic ester 6 (26\%), although the presence of such a salt is considered essential for efficient generation of $\mathbf{4}$ from carbonyl compounds (Scheme 1) [5]; this observation lends support to the notion that the principal role of $\mathrm{LiBr}$ is to facilitate oxaphosphetane ring opening to enable subsequent lithiation, and its presence does not significantly influence subsequent reaction steps, at least with this electrophile. While simple phosphoranes $\left(\mathrm{Ph}_{3} \mathrm{PCH}_{2}\right.$ and $\mathrm{Ph}_{3} \mathrm{PCHMe}$ ) are known to react with epoxides (32-68\% yields) in the presence of soluble lithium halides [33,34], the homoallylic alcohol, which would arise [35] from any reaction of $\beta$-lithiooxyphosphonium ylide and terminal epoxide, was not observed in the present studies; this suggests that the latter ylides are not capable of reacting with terminal epoxides [35], or the presence of LTMP and/or $\mathrm{PPh}_{3}$ prevents this reaction from occurring.

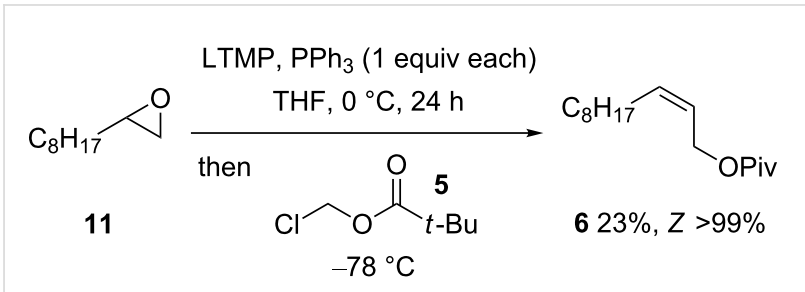

Scheme 3: Z-Allylic ester 6 from epoxide 11.

The original study on the reaction between LTMP and terminal epoxides in THF showed this to be an efficient way to prepare the corresponding isomerized aldehydes [20] (later established as proceeding through an intermediate TMP enamine) [36,37]. In the present work, neither decanal nor its corresponding TMP enamine were not detected as side-products, and we also established that the presence of $\mathrm{LiBr}$ (1 equiv) did not interfere in this isomerization process, giving decanal from epoxide $\mathbf{1 1}$ in $65 \%$ yield (67\% without $\mathrm{LiBr})$ and with no unreacted epoxide observed. The use of shorter reaction times $(2-4 \mathrm{~h})$ for the generation of the epoxide-derived ylide $4\left(R^{2}=H\right)$, including increasing the quantities of $\mathrm{LTMP}$ and $\mathrm{Ph}_{3} \mathrm{P}$ (to 3 equiv), or the use of $t$-BuOMe as solvent [21,22], did not lead to improved yields of ester 6.

As terminal epoxides are readily available as single enantiomers [38,39], it was considered important to study the possibility of using an aldehyde electrophile with the epoxidederived ylide. This would provide an entry into allylic alcohols 
[40], where the epoxide stereocentre is preserved in the product $[17,18]$. In the event, benzaldehyde was successfully trapped to give $E$-allylic alcohol 7 in up to $33 \%$ yield (Scheme 4) by using LTMP ( 1 equiv), $\mathrm{Ph}_{3} \mathrm{P}$ (5 equiv) and $\mathrm{LiBr}$ ( 2 equiv; $24 \%$ yield in the absence of $\mathrm{LiBr}$ ). Essentially the same yields ( $31 \%$ and $30 \%$ ) were obtained under otherwise identical conditions but with 2 equiv of $\mathrm{Ph}_{3} \mathrm{P}$, or with excess LTMP (3 equiv) and $\mathrm{Ph}_{3} \mathrm{P}$ ( 9 equiv). Other experimental variations (use of substoichiometric TMP ( 0.25 equiv) [22] or substitution of $\mathrm{LiBr}$ by $\mathrm{LiCl})$ did not improve the yield of alcohol 7 (20\% and $10 \%$, respectively), whereas substitution of $\mathrm{Ph}_{3} \mathrm{P}$ by $\mathrm{Bu}_{3} \mathrm{P}$ or $\mathrm{Cy}_{3} \mathrm{P}$ did not lead to the orange-red colouration suggestive of ylide formation, and only starting epoxide 11 was observed.

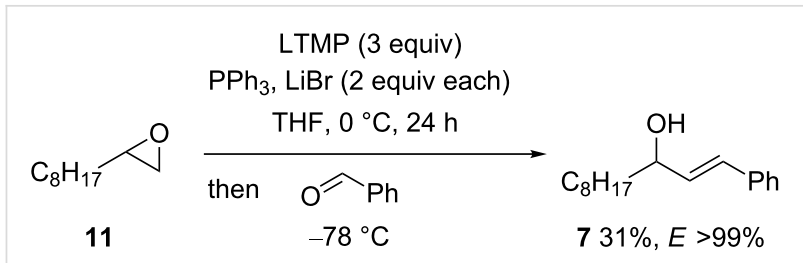

Scheme 4: E-allylic alcohol 7 from epoxide 11.

We also studied the possibility of generating alcohol 7 from terminal epoxide 11 using an organolithium instead of a hindered lithium amide as the base (Scheme 5). Organolithiums, in particular secondary and tertiary organolithiums, are known to react with terminal epoxides by $\alpha$-lithiation, although this is typically followed by trapping of the $\alpha$-lithiated epoxide with a second equivalent of the organolithium and elimination of $\mathrm{Li}_{2} \mathrm{O}$ to give an $E$-alkene (e.g., 12): a process referred to as reductive alkylation [41]. Also, while $\mathrm{PPh}_{3}$ is itself capable of being lithiated-carboxylated (at a meta-position, $6 \%$ yield) by using $\mathrm{BuLi}$ in $\mathrm{Et}_{2} \mathrm{O}$ [42], this requires significantly higher temperatures (reflux, $46 \mathrm{~h}$ ) than those applied here. In the event, the use of either $s$-BuLi or $t$-BuLi with epoxide 11 in the presence of $\mathrm{Ph}_{3} \mathrm{P}$ in a variety of solvents (THF, $\mathrm{Et}_{2} \mathrm{O}, t$-BuOMe, toluene) followed by the addition of benzaldehyde was found to give allylic alcohol 7, albeit in low yields with reductive alkylation always being the dominant reaction pathway, and typically $\sim 30 \%$ of epoxide 11 and $\sim 60 \% \mathrm{Ph}_{3} \mathrm{P}$ being recovered. The highest yield

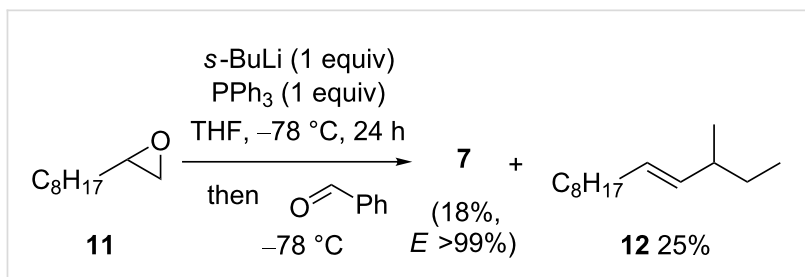

Scheme 5: E-allylic alcohol 7 and alkene 12 from epoxide 11 by using s-BuLi. of allylic alcohol 7 (18\%) was obtained by using $s$-BuLi in $\mathrm{Et}_{2} \mathrm{O}$ at $-78{ }^{\circ} \mathrm{C}$ with a $24 \mathrm{~h}$ lithiation time (Scheme 5 ); lithiation by using other organolithiums ( $t$-BuLi, $\mathrm{PhLi}, \mathrm{BuLi}, \mathrm{MeLi})$, or at higher or lower temperatures $\left(-90^{\circ} \mathrm{C}\right.$ or $\left.-40^{\circ} \mathrm{C}\right)$, for a longer period (48 h) or in the presence of increased $\mathrm{Ph}_{3} \mathrm{P}$ ( 2 equiv), or TMEDA (1 equiv) or $\mathrm{LiBr}$ ( 2 equiv) as additives were all less effective.

The use of a proton (deuterium) source as the electrophile to trap an epoxide-derived ylide prepared by using LTMP was next examined. This was anticipated to provide a base-induced method to deoxygenate epoxides [43], which in the case of deuteration would provide a regiospecific and potentially stereoselective entry to 1 -deuterated terminal alkenes $[44,45]$. Use of a slightly higher molecular weight epoxide, 1,2-epoxydodecane (13) to facilitate product isolation, gave dodecene (14) $(41 \%, 50 \% \mathrm{D}[46])$ after reaction with $\mathrm{CD}_{3} \mathrm{OD}$ (Scheme 6), where the deuterium incorporation was nonstereoselective [44]. Modest deuterium incorporation suggests partial collapse of the intermediate $\beta$-lithiooxy ylide occurs under the conditions of its generation, by elimination of $\mathrm{Ph}_{3} \mathrm{PO}$ after or before protonation (e.g., from solvent) and before electrophile addition. Dodecene was also observed as a byproduct in the corresponding reaction of epoxide 13 with benzaldehyde, supporting this hypothesis.

LTMP (1 equiv)
Scheme 6: Terminal alkene 14 from epoxide 13.
then $\mathrm{CD}_{3} \mathrm{OD}$
$-78{ }^{\circ} \mathrm{C}$

\section{Conclusion}

Among phosphoranes, $\beta$-lithiooxyphosphonium ylides occupy a special place, because of their utility in Wittig-Schlosser and SCOOPY-type stereoselective olefination reactions [1-19]. Here we have shown a new and concise method to such valuable intermediates, directly from readily available terminal epoxides. Significantly, the work validates the compatibility of lithium amide and phosphine to generate such ylides, whose intermediacy is demonstrated by representative alkene-forming reactions with chloromethyl pivalate, benzaldehyde and $\mathrm{CD}_{3} \mathrm{OD}$, giving a $Z$-allylic pivalate, a conjugated $E$-allylic alcohol and a partially deuterated terminal alkene, respectively. High stereochemical control is retained in the $Z$-allylic pivalate and $E$-allylic alcohol syntheses. While the overall yields for the transformations are modest, they stand up to comparison with the earlier methods, given the experimental simplicity and brevity of the current approach. 


\section{Supporting Information}

\section{Supporting Information File 1}

Preparative details of 6, 7, 12 and 14 are reported, together with their spectroscopic data.

[http://www.beilstein-journals.org/bjoc/content/ supplementary/1860-5397-8-219-S1.pdf]

\section{References}

1. Gosney, I.; Rowley, A. G. Transformations via phosphorus-stabilized anions. 1. Stereoselective synthesis of alkenes. In Organophosphorus Reagents in Organic Synthesis; Cadogan, J. I., Ed.; Academic Press: New York, 1979; pp 17-153.

2. Maryanoff, B. E.; Reitz, A. B. Chem. Rev. 1989, 89, 863-927. doi:10.1021/cr00094a007

3. Vedejs, E.; Peterson, M. J. Top. Stereochem. 1994, 21, 1-157. doi:10.1002/9780470147306.ch1

4. Schobert, R.; Hözel, C.; Barnickel, B. Wittig and related phosphorus-based alkenations. In Science of Synthesis; de Meijere, A., Ed.; Thieme: Stuttgart, Germany, 2010; Vol. 47a, pp 9-84.

5. Wang, Q.; Deredas, D.; Huynh, C.; Schlosser, M. Chem.-Eur. J. 2003, 9, 570-574. doi:10.1002/chem.200390061

6. Hodgson, D. M.; Arif, T. J. Am. Chem. Soc. 2008, 130, 16500-16501. doi:10.1021/ja8076999

7. Hodgson, D. M.; Arif, T. Org. Lett. 2010, 12, 4204-4207. doi:10.1021/ol101843q

8. Hodgson, D. M.; Arif, T. Chem. Commun. 2011, 47, 2685-2687. doi:10.1039/c0cc04429f

9. Hodgson, D. M.; Persaud, R. S. D. Org. Biomol. Chem. 2012, 10, 7949-7951. doi:10.1039/c2ob26346g

10. Corey, E. J.; Shirahama, H.; Yamamoto, H.; Terashima, S.; Venkateswarlu, A.; Schaaf, T. K. J. Am. Chem. Soc. 1971, 93, 1490-1491. doi:10.1021/ja00735a032

11. Corey, E. J.; Niwa, H.; Knolle, J. J. Am. Chem. Soc. 1978, 100, 1942-1943. doi:10.1021/ja00474a058

12. Corey, E. J.; Marfat, A.; Hoover, D. J. Tetrahedron Lett. 1981, 22, 1587-1590. doi:10.1016/S0040-4039(01)90384-3

13. Schwarz, S.; Weber, G.; Depner, J.; Schaumann, J. Tetrahedron 1982 , 38, 1261-1268. doi:10.1016/0040-4020(82)85112-0

14. Russell, S. W.; Pabon, H. J. J. J. Chem. Soc., Perkin Trans. 11982 , 545-552. doi:10.1039/P19820000545

15. Johnson, F.; Paul, K. G.; Favara, D.; Ciabatti, R.; Guzzi, U. J. Am. Chem. Soc. 1982, 104, 2190-2198. doi:10.1021/ja00372a015

16. Yadagiri, P.; Shin, D.-S.; Falck, J. R. Tetrahedron Lett. 1988, 29 , 5497-5500. doi:10.1016/S0040-4039(00)80796-0

17. Kubota, T.; Yamamoto, M. Tetrahedron Lett. 1992, 33, 2603-2606. doi:10.1016/S0040-4039(00)92255-X

18. Okuma, K.; Tanaka, Y.; Ohta, H.; Matsuyama, H. Bull. Chem. Soc. Jpn. 1993, 66, 2623-2632. doi:10.1246/bcsj.66.2623

19. El Fangour, S.; Guy, A.; Vidal, J.-P.; Rossi, J.-C.; Durand, T. J. Org. Chem. 2005, 70, 989-997. doi:10.1021/jo048179+

20. Yanagisawa, A.; Yasue, K.; Yamamoto, $\mathrm{H}$. J. Chem. Soc., Chem. Commun. 1994, 2103-2104. doi:10.1039/C39940002103

21. Hodgson, D. M.; Chung, Y. K.; Paris, J.-M. J. Am. Chem. Soc. 2004, 126, 8664-8665. doi:10.1021/ja047346k
22. Hodgson, D. M.; Chung, Y. K.; Nuzzo, I.; Freixas, G.; Kulikiewicz, K. K.; Cleator, E.; Paris, J.-M. J. Am. Chem. Soc. 2007, 129, 4456-4462. doi:10.1021/ja0672932

23. Hodgson, D. M.; Bray, C. D.; Kindon, N. D. Org. Lett. 2005, 7, 2305-2308. doi:10.1021/ol050402h

24. Hodgson, D. M.; Bray, C. D.; Humphreys, P. G. Synlett 2006, 1-22. doi:10.1055/s-2005-921925

25. Hodgson, D. M.; Humphreys, P. G.; Hughes, S. P. Pure Appl. Chem. 2007, 79, 269-279. doi:10.1351/pac200779020269

26. Padwa, A.; Hornbuckle, S. F. Chem. Rev. 1991, 91, 263-309. doi:10.1021/cr00003a001

27. Seyferth, D.; Grim, S. O.; Read, T. O. J. Am. Chem. Soc. 1960, 82, 1510-1511. doi:10.1021/ja01491a066

28. Seyferth, D.; Grim, S. O.; Read, T. O. J. Am. Chem. Soc. 1961, 83, 1617-1620. doi:10.1021/ja01468a017

29. Wittig, G.; Schlosser, M. Angew. Chem. 1960, 72, 324. doi:10.1002/ange.19600720913

30. Wittig, G.; Schlosser, M. Chem. Ber. 1961, 94, 1373-1383. doi:10.1002/cber.19610940532

31. Khaskin, B. A.; Molodova, O. D.; Torgasheva, N. A. Russ. Chem. Rev. 1992, 61, 306-334. doi:10.1070/RC1992v061n03ABEH000947

32. Rönnholm, P.; Hilmersson, G. ARKIVOC 2011, No. v, 200-210. http://www.arkat-usa.org/get-file/38691

33. Schlosser, M.; Tuong, H. B.; Respondek, J.; Schaub, B. Chimia 1983, $37,10-11$.

34. Materal-Saadi, M. S. Phosphorus, Sulfur Silicon Relat. Elem. 2000 , 164, 269-275. doi:10.1080/10426500008045252

35. Heath, R. R.; Doolittle, R. E.; Sonnet, P. E.; Tumlinson, J. H. J. Org. Chem. 1980, 45, 2910-2912. doi:10.1021/jo01302a032

36. Hodgson, D. M.; Bray, C. D.; Kindon, N. D. J. Am. Chem. Soc. 2004, 126, 6870-6871. doi:10.1021/ja031770o

37. Hodgson, D. M.; Bray, C. D.; Kindon, N. D.; Reynolds, N. J.; Coote, S. J.; Um, J. M.; Houk, K. N. J. Org. Chem. 2009, 74, 1019-1028. doi:10.1021/jo802016t

38. Schaus, S. E.; Brandes, B. D.; Larrow, J. F.; Tokunaga, M.; Hansen, K. B.; Gould, A. E.; Furrow, M. E.; Jacobsen, E. N. J. Am. Chem. Soc. 2002, 124, 1307-1315. doi:10.1021/ja016737।

39. Keith, J. M.; Larrow, J. F.; Jacobsen, E. N. Adv. Synth. Catal. 2001, 343, 5-26. doi:10.1002/1615-4169(20010129)343:1<5::AID-ADSC5>3.0.CO;2-I

40. Hodgson, D. M.; Humphreys, P. G. Allylic alcohols. In Science of Synthesis; Clayden, J., Ed.; Thieme: Stuttgart, Germany, 2007; Vol. 32 , pp 583-665.

41. Doris, E.; Dechoux, L.; Mioskowski, C. Tetrahedron Lett. 1994, 35, 7943-7946. doi:10.1016/0040-4039(94)80017-0

42. Gilman, H.; Brown, G. E. J. Am. Chem. Soc. 1945, 67, 824-826. doi:10.1021/ja01221a039

43. Murai, S.; Murai, T.; Kato, S. Reduction of epoxides. In Comprehensive Organic Synthesis; Trost, B. M.; Fleming, I., Eds.; Pergamon: Oxford, U.K., 1991; Vol. 8, pp 871-893. doi:10.1016/B978-0-08-052349-1.00249-3

44. Schlosser, M.; Christmann, K.-F. Synthesis 1969, 38-39.

45. Schlosser, M.; Christmann, K.-F.; Piskala, A. Chem. Ber. 1970, 103, 2814-2820. doi:10.1002/cber.19701030915

46. Oda, H.; Sato, M.; Morizawa, Y.; Oshima, K.; Nozaki, H. Tetrahedron Lett. 1983, 24, 2877-2880. doi:10.1016/S0040-4039(00)88048-X 


\section{License and Terms}

This is an Open Access article under the terms of the Creative Commons Attribution License

(http://creativecommons.org/licenses/by/2.0), which permits unrestricted use, distribution, and reproduction in any medium, provided the original work is properly cited.

The license is subject to the Beilstein Journal of Organic Chemistry terms and conditions:

(http://www.beilstein-journals.org/bjoc)

The definitive version of this article is the electronic one which can be found at:

doi:10.3762/bjoc.8.219 